\title{
Aerosol vehicle for delivery of epidermal cells - An in vitro study
}

\author{
Andre Bahoric DVM MSc, A Robertson Harrop MD MSc FRCSC, Howard M Clarke MD PhD FRCSC FACS, \\ Ronald M Zuker MD FRCSC FACS \\ Division of Plastic Surgery and Cryopreservation Laboratory, The Hospital for Sick Children, \\ Toronto, Ontario
}

\begin{abstract}
A Bahoric, AR Harrop, HM Clarke, RM Zuker. Aerosol vehicle for delivery of epidermal cells - An in vitro study. Can J Plast Surg 1997;5(3):153-156. This in vitro study investigated the possibility of delivering epidermal cells to cell culture plates using a simple and inexpensive aerosolization apparatus. Full-thickness skin biopsies were incubated in dispase to separate the epidermis from the dermis, and the epidermis was treated with trypsin to separate the epidermal cells from one another. The cells were suspended in aerosolization medium $\left(1 \times 10^{6}\right.$ cells $/ \mathrm{mL}$ ) and sprayed onto culture plates using a sterilized pump-action aerosol nozzle. The plates were incubated and microscopically examined on a daily basis. The aerosolization process was successful in consistently delivering a uniform distribution of suspended epidermal cells. By day 4 there was evidence of cell proliferation, and by days 7 to 9 a confluent layer of cells was achieved on the plates. The monolayer consisted primarily of keratinocytes interspersed with a few fibroblasts. The aerosol method was shown to be effective at delivering a suspension of viable epidermal cells to a culture plate.
\end{abstract}

Key Words: Aerosol, Delivery, Epidermal cells, Keratinocytes

\section{Aérosol pour la vaporisation des cellules épidermiques, étude in vitro}

RÉSUMÉ : Cette étude in vitro se penchait sur la possibilité de vaporiser les cellules épidermiques sur les milieux de cultures cellulaires à l'aide d'un simple appareil d'aérosol peu coûteux. Des biopsies de peau pleine épaisseur ont été mises en incubation dans la dispase afin de séparer l'épiderme du derme et l'épiderme a été traité à la trypsine pour séparer les cellules épidermiques les unes des autres. Les cellules ont été mises en suspension dans un véhicule aérosol $\left(1 \times 10^{6}\right.$ cellules $\left./ \mathrm{mL}\right)$ et vaporisées sur des milieux de culture à l'aide d'une buse aérosol sous forme de pompe stérilisée. Les milieux de culture ont été placés en incubation, puis examinés par microscope sur une base quotidienne. Le processus d'aérosol a réussi à offrir avec constance une distribution uniforme des cellules épidermiques en suspension. Au jour 4, on notait des signes de prolifération cellulaire et aux jours 7 à 9, une couche de cellules continues a pu être observée sur les milieux de culture. La monocouche était composée principalement de kératinocytes et de quelques nouveaux fibroblastes. L'aérosol s'est révélé efficace pour la distribution d'une suspension de cellules épidermiques viables sur les milieux de culture.

$\mathrm{E}$ arly coverage of large burn wounds is often limited by the availability of donor sites for skin grafts. One solution to this problem is the use of cultured epithelial autografts, whereby a small sample of uninjured skin is obtained from the patient and its keratinocytes are grown in a cell culture environment. Over a three to four week period the number of cells can be expanded more than 5000-fold, yielding enough cells to cover virtually the entire body surface area of an adult patient (1-3). Most commonly, the cultured

Correspondence and reprints: Dr Howard M Clarke, Division of Plastic Surgery, The Hospital for Sick Children, 555 University Avenue, Toronto, Ontario M5G 1X8. Telephone 416-813-6444, fax 416-813-6147, e-mail howard.clarke@utoronto.ca cells are then attached to a backing of fine mesh gauze and placed onto the debrided wound (4-7). The process of applying the cells onto the gauze, and then onto the patient, is time-consuming and labour intensive. In addition, a large container is required to house the sheets of gauze while the cells are transferred from the laboratory to the clinical facility where the cells will be applied to the patient. It is speculated that a simpler process would involve suspending keratinocytes in a solution that could be sprayed as an aerosol onto the wound.

This in vitro study investigated the possibility of delivering epidermal cells to a cell culture plate via an aerosol vehicle. A simple and inexpensive method is described for aerosolized delivery of cells to the culture plate. 


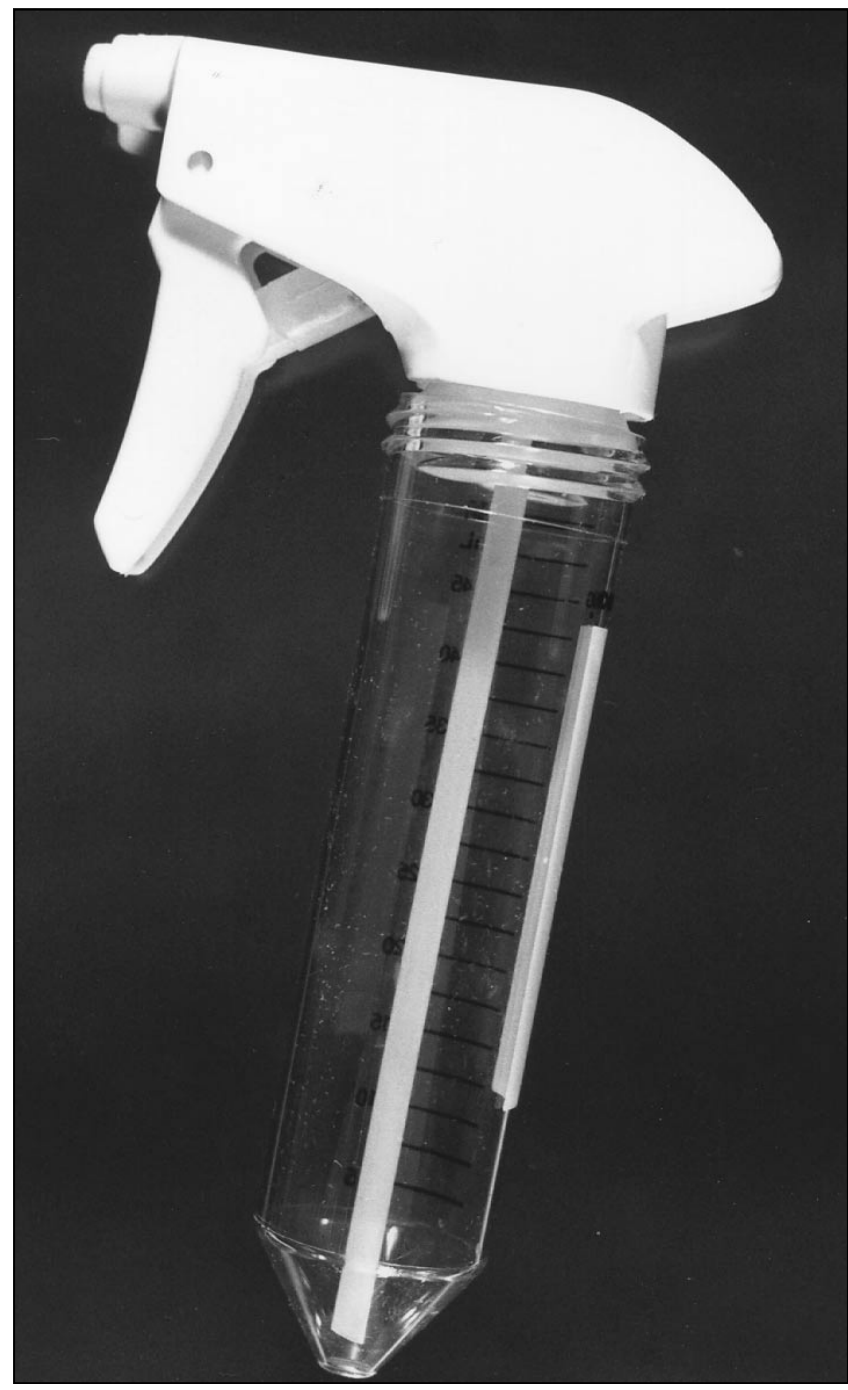

Figure 1) Pump-action aerosol nozzle attached to $50 \mathrm{~mL}$ vial used to deliver aerosolized epidermal cell suspension to the culture plates

\section{MATERIALS AND METHODS}

Epidermal cells used in this experiment were obtained during setback otoplasty procedures, from the full-thickness skin on the medial surface of the ear - skin that is normally discarded. Full-thickness skin samples measuring approximately $1 \times 2 \mathrm{~cm}$ were obtained in this way from seven children (ages 5 to 14 years) undergoing surgery for prominent ears at The Hospital for Sick Children, Toronto, Ontario.

Full-thickness skin samples from each patient were placed in chilled RPMI 1640 transport medium (JRH Biosciences, Kansas), supplemented with polymixin B $(100 \mu \mathrm{g} / \mathrm{mL})$, vancomycin $(50 \mu \mathrm{g} / \mathrm{mL})$, lincomycin $(120 \mu \mathrm{g} / \mathrm{mL})$, cefoxitin $(240 \mu \mathrm{g} / \mathrm{mL})$ and amphotericin B $(10 \mu \mathrm{g} / \mathrm{mL})$. The samples were stored at $4^{\circ} \mathrm{C}$ for up to $6 \mathrm{~h}$. The samples were rinsed with Ringer's lactate, placed in dispase solution $(24 \mathrm{U} / \mathrm{mL})$ and incubated at $4^{\circ} \mathrm{C}$ for 12 to $16 \mathrm{~h}$. The epidermis was then separated from the dermis with forceps, and the dermis was discarded. The remaining epidermis was cut into $1 \mathrm{~mm}^{2}$ pieces with a scalpel blade. These epidermal fragments were

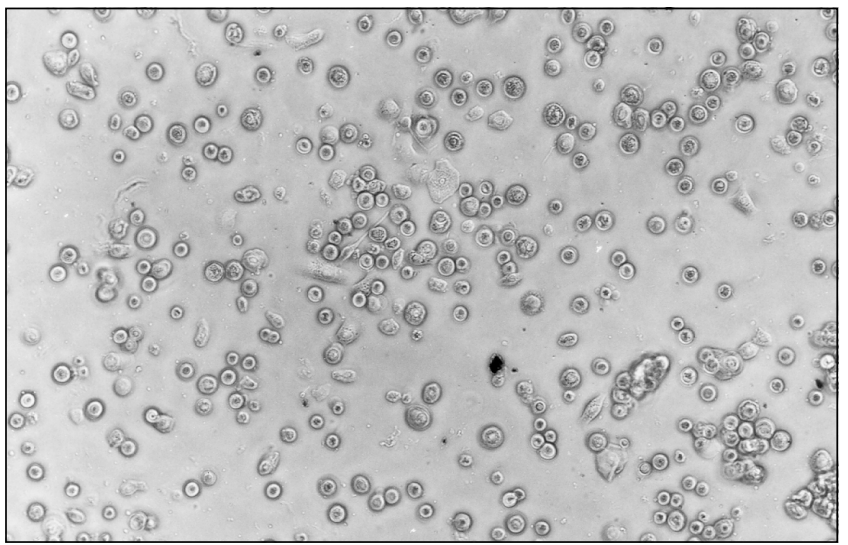

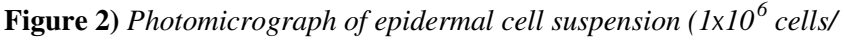
$m L$ ) immediately after delivery to the culture plate (10x magnification)

then treated with trypsin $(0.25 \%$ in ethylenediamine-tetraacetic acid) and incubated for 90 mins at $37^{\circ} \mathrm{C}$ with periodic, gentle agitation. This process separates epidermal cells from one another in preparation for aerosolization. After trypsinization was complete, the cells were suspended in aerosolization medium (RPMI 1640 medium supplemented with 10\% fetal calf serum [Cansera], penicillin [50 U/mL] and streptomycin $[50 \mu \mathrm{g} / \mathrm{mL}])$. A hemocytometer was used to determine the concentration of cells in the aerosol. Fifteen millilitres of suspended epidermal cells $\left(1 \times 10^{6}\right.$ cells $\left./ \mathrm{mL}\right)$ were placed in $50 \mathrm{~mL}$ sterile vials (Corning, New York), which were then attached to a sterilized pump-action aerosol nozzle (commercially available, modified in our laboratory) (Figure 1). The suspension was agitated just before aerosolization, then sprayed (using the 'coarse mist' mode on the nozzle) onto $10 \mathrm{~cm}$ cell culture plates (Becton-Dickinson, New Jersey). The plates were then incubated at $37^{\circ} \mathrm{C}, 5 \%$ Carbon dioxide and $75 \%$ humidity. The medium was replaced after $24 \mathrm{~h}$ with complete keratinocyte medium (Gibco, New York), supplemented with penicillin $(50 \mathrm{U} / \mathrm{mL})$ and streptomycin $(50 \mu \mathrm{g} / \mathrm{mL})$ and then exchanged with fresh medium every two days. The plates were examined by phase contrast microscopy on a daily basis, and photographs were taken to document progress.

\section{RESULTS}

The aerosolization process was successful at delivering a uniform distribution of suspended epidermal cells from each of the seven patients to the culture plates (Figure 2). In each case, most of the suspension consisted of individual cells; however, some aggregates of cells were noted. After incubation for $24 \mathrm{~h}$ (day 1), some cells were attached to the surface of the culture plates (Figure 3). It was apparent that many of these attached cells were keratinocytes; however, fibroblasts were also present. By day 3 (Figure 4) there was evidence of considerable cell proliferation with increased density of keratinocytes and, to a lesser extent, fibroblasts. A further increase in cell density was observed on day 5 (Figure 5). A confluent layer of cells was achieved on the plates by days 7 to 9 (Figure 6): the monolayer consisted primarily of kera- 


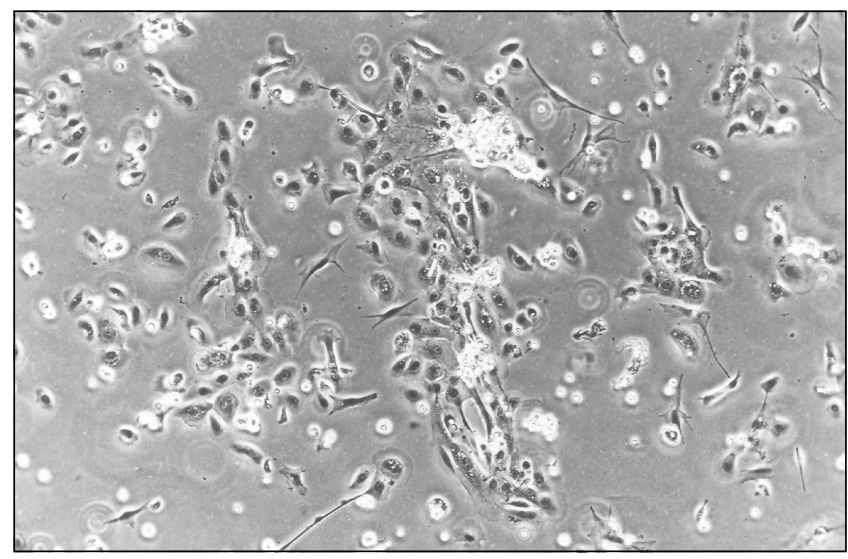

Figure 3) Epidermal cells on the culture plate after $24 \mathrm{~h}$ incubation (day 1). Many cells have adhered to the plate surface (10x magnification)

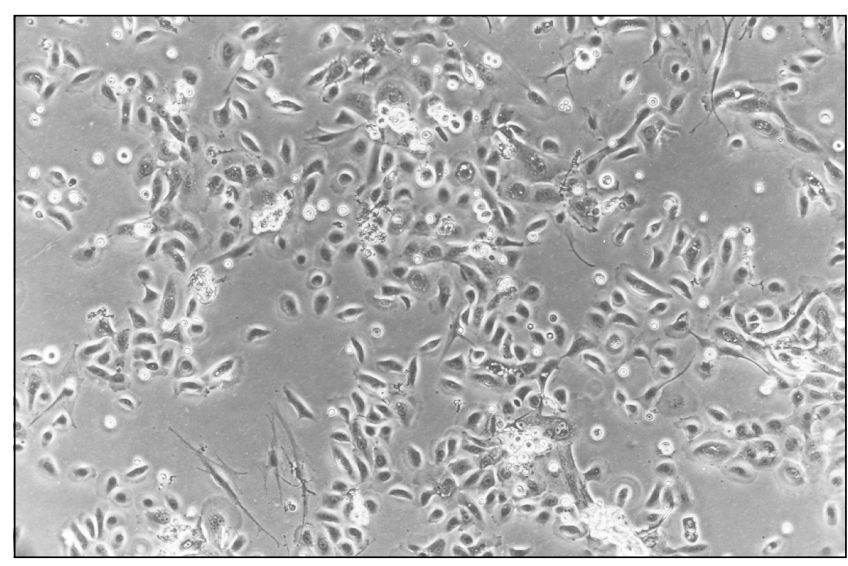

Figure 4) After incubation for three days there is evidence of cell proliferation (10x magnification)

tinocytes interspersed with a few fibroblasts and the occasional dendritic cell (presumed to be Langerhan's cells).

\section{DISCUSSION}

Burns covering more than $60 \%$ of the patient's total body surface present a special challenge because donor skin is only available in small amounts relative to the size of the open wound requiring coverage. The traditional approach to treating these patients is to graft as much of the burned wound as possible, given the amount of donor skin available, and then to wait one to two weeks until the donor sites have reepithelialized, after which time the donor sites are reharvested. This process is repeated until all wounds are closed.

One solution to the problem of limited donor sites, first described by Rheinwald and Green in 1975 (1), is the multiplication of epidermal cells in a cell culture environment. This process involves obtaining small samples of skin from uninjured donor areas. The dermis is separated from the epidermis with dispase, a protein-digesting enzyme. The remaining epidermis is treated with trypsin, an enzyme that dissociates epidermal cells (mostly keratinocytes) from one another. The keratinocytes are transferred to a cell culture environment, placed onto a bed of lethally irradiated fibroblasts

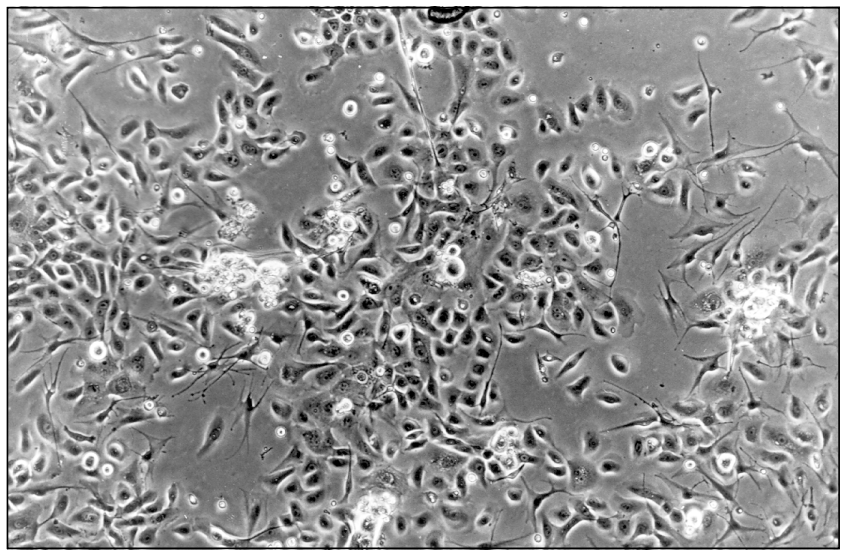

Figure 5) After five days there is further increase in cell density. The cells with the cobble-stone pattern are keratinocytes while those with a spindle shape are fibroblasts (10x magnification)

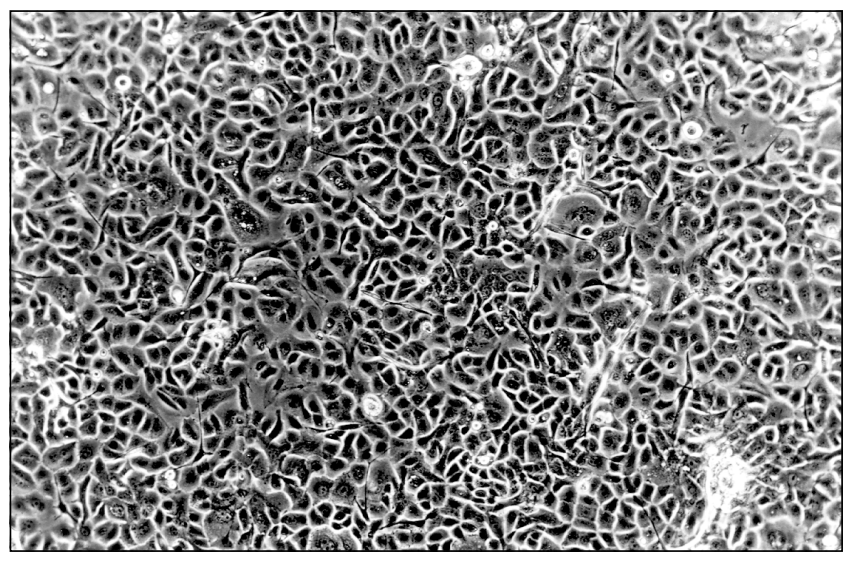

Figure 6) Confluent layer of cells is seen by day 8(10x magnification)

within a culture vessel and grown in the presence of a medium containing epidermal growth factor (2). Starting with a $3 \mathrm{~cm}^{2}$ split-thickness skin biopsy, the area of epithelium can be expanded more than 5000-fold within three to four weeks, yielding enough epithelial sheets to cover the body surface of an adult human (approximately $1.7 \mathrm{~m}^{2}$ ) (3).

In 1981, O'Connor et al (4) successfully performed grafts of cultured epithelial cells in human burn patients. The sheets of keratinocytes, expanded in culture by the Rheinwald and Green technique, were attached to a backing of fine mesh gauze and applied to the patients' wounds. Since then there have been other reports of successful clinical use of cultured epithelial autografts in patients, adult and child, with burns covering up to $90 \%$ of the total body surface area (5-7). Cultured epithelial autografts have also been used in large cutaneous wounds other than burns. Examples include giant congenital pigmented nevi (8), epidermolysis bullosa (9) and even smaller wounds such as chronic leg ulcers $(10,11)$.

Current clinical techniques for application of cultured epithelial autografts involve carefully transferring the confluent epithelial cells from the culture dish to a backing of fine mesh gauze. This technique is time-consuming and labor intensive. Also, a large container is required to house the sheets of gauze while the cells are transferred from the labo- 
ratory to the clinical facility where the cells will be applied to the patient. One proposed method, studied in pigs, to circumvent delivery problems involved the use of water-tight vinyl chambers placed over full-thickness wounds. Autologous keratinocyte suspensions were then placed inside these chambers and were found to adhere to the wound and proliferate on its surface (12-14).

The authors of this paper examined another solution, whereby a suspension of epidermal cells was delivered to the target (in this case a cell culture plate) in aerosol form. This method was successful in delivering a uniform distribution of cells to the plate. The epidermal cells were, in turn, observed to proliferate over the surface of the plate, forming a confluent monolayer within seven to nine days. The monolayer consisted chiefly of keratinocytes interspersed with a small number of fibroblasts. Fibroblasts were present because the epidermal cell suspension was prepared directly from fullthickness skin biopsies. In the culture setting, where the cells are first multiplied in a culture environment, gradual overgrowth of fibroblasts relative to keratinocytes may be a problem. For this reason the Rheinwald and Green technique involves culturing the epidermal cells in the presence of lethally irradiated fibroblasts, which suppress fibroblast multiplication (2).

It is believed that the aerosol vehicle may be useful in other laboratory and clinical settings. The authors are cur-

\section{REFERENCES}

1. Rheinwald JG, Green H. Serial cultivation of strains of human epidermal keratinocytes: The formation of keratinizing colonies from single cells. Cell 1975;6:331-44.

2. Green H. Cultured cells for the treatment of disease. Sci Am 1991;265:96-102.

3. Green H, Kehinde O, Thomas J. Growth of cultured human epithelial cells into multiple epithelia suitable for grafting. Proc Natl Acad Sci USA 1979;76:5665-8.

4. O'Connor NE, Mulliken JB, Banks-Schlegel S, Kehinde O, Green H. Grafting of burns with cultured epithelium prepared from autologous epidermal cells. Lancet 1981;i:75-8.

5. Gallico GG, O'Connor NE, Compton CC, Kehinde O, Green H. Permanent coverage of large burn wounds with autologous cultured human epithelium. N Engl J Med 1984;331:448-51.

6. DeLuca M, Albanese E, Bondanza S, et al. Multicentre experience in the treatment of burns with autologous and allogenic cultured epithelium, fresh or preserved in a frozen state. Burns 1989;15:303-9.

7. McAree KG, Klein RL, Boeckman CR. The use of cultured epithelial autografts in the wound care of severely burned patients. J Pediatr Surg 1993;28:166-8. rently in the process of developing an in vivo model, in which a suspension of epidermal cells is delivered to a wound in an animal. This work may eventually lead to the development of a cost- and personnel-efficient way of providing cultured epithelial cell coverage in clinical settings such as extensive burns or other cutaneous injuries. Another potential application of this technique, particularly in the pediatric population, is in scald burns. In these cases, there is often a deep, partialthickness injury that leaves behind a small portion of the dermis, from which the epidermis can gradually be regenerated from epithelial cells present in the remnants of glands and hair follicles. It was speculated that 'spraying' the wound with a layer of autologous epithelial cells may speed up the healing process in this situation.

\section{SUMMARY}

A method was developed for delivering a suspension of epidermal cells to a cell culture plate using an aerosol vehicle. It was possible to deliver consistently a uniform distribution of cells to the plate. Over a subsequent period of seven to nine days the cells proliferated on the plate to form a confluent monolayer, comprised primarily of keratinocytes. The authors are now in the process of applying the technique to an experimental animal model. It is hoped that the aerosol vehicle may eventually prove clinically useful, for delivery of keratinocytes to human wounds.

8. Gallico GG, O'Connor NE, Compton CC, Remensnyder JP, Kehinde $\mathrm{O}$, Green H. Cultured epithelial autografts for giant congenital nevi. Plast Reconstr Surg 1989;84:1-9.

9. Carter DM, Lin AN, Varghese MC, Caldwell D, Pratt LA, Elsinger M. Treatment of junctional epidermolysis bullosa with epidermal autografts. J Am Acad Dermatol 1987;172:246-50.

10. Hefton JM, Weksler M, Parris A, Caldwell D, Balin AK, Carter DM. Grafting of skin ulcers with cultured autologous epidermal cells. J Invest Dermatol 1983;80:322. (Abst)

11. Carver N, Leigh IM. Keratinocyte grafts and skin equivalents. Int J Dermatol 1991;30:540-1.

12. Andree C, Page C, Vogt P, Hatzis D, Eriksson E. Direct comparison of cultured epidermal sheet grafts and keratinocyte suspensions in a liquid environment in pigs. Annual Meeting of American Burn Association, Orlando, Florida, April, 1994.

13. Breuing K, Eriksson E, Liu P, Miller DR. Healing of partial thickness porcine skin wounds in a liquid environment. J Surg Res 1992;52:50-8.

14. Vogt PM, Thompson S, Andree C, et al. Genetically modified keratinocytes transplanted to wounds reconstitute the epidermis. Proc Natl Acad Sci USA 1994;91:9307-11. 